\title{
Haematocrit, Glycosylated Haemoglobin and Diabetic Microangiopathy
}

Dear Sir,

Bodansky et al. in a letter to the editor (Diabetologia 19: 163, 1980) commented on the paper of Graham et al. (Diabetologia 18: 205,1980 ) and questioned their finding of a weak positive correlation $(r=0.32)$ of total red cell count to glycosylated haemoglobin in 110 adult diabetic patients. However, the patient data Bodansky et al. presented for this argument had unknown sex distributions (packed cell volume smaller for females) and included patients with vascular complications and even renal insufficiency (anaemia), conditions which most often respond to hypoxia by an increase in red cell 2,3-diphosphoglycerate (2,3-DPG). It is obvious that a strong case cannot be made with such data.

We recently performed a study of oxygen transport parameters in ambulatory diabetic children. By studying children as opposed to adults one avoids the influence of factors such as smoking, differences in haemoglobin concentrations according to sex, and asymptomatic cardiovascular disease, which are likely to interfere with possible associations between oxygen parameters.

The Table shows our findings. Haemoglobin concentration, haematocrit and red cell 2,3-DPG concentration were all significantly elevated in the diabetic children as compared to the healthy children $(p<0.005)$, and haemoglobin, haematocrit and erythrocyte count correlated to glycosylated haemoglobin with correlation coefficients similar to that of Graham et al.

Our interpretation of these results differs somewhat from that of Graham et al. They suggested that the greater proportion of high oxygen-affinity $\mathrm{Hb} \mathrm{A}_{\mathrm{I}}$ in comparatively uncontrolled diabetics may be inducing sufficient tissue hypoxia to cause the demonstrated relative polycythaemia. Our studies have shown that $\mathrm{Hb}_{1}$ per se has only a minor effect on the oxygen dissociation curve. Of more importance is the fact that high $\mathrm{Hb} \mathrm{A}_{\mathrm{I}}$ indicates poor regulation of blood glucose often with fluctuating blood sugars. Each time the blood sugar falls and a rapid carbohydrate utilization takes place in insulin-sensitive tissues, a lowering occurs in plasma inorganic phosphate which in the red cells leads to a relative decrease in 2.3-DPG and thereby to a fluctuating condition of affinity hypoxia [1-3].

\section{References}

1. Ditzel J (1979) Changes in red cell oxygen release capacity in diabetes mellitus. Fed Proc 38: 2484-2488

2. Ditzel J, Jæger P, Kjærgaard JJ (1979) Hemoglobin $A_{\mathrm{Ic}}$ and red cell oxygen-releasing capacity in relation to early microvascular responses in ambulatory diabetics. Adv Microcirc 8: 1-13

3. Ditzel J (1980) Affinity hypoxia as a pathogenetic factor of microangiopathy with particular reference to diabetic retinopathy. Acta Endocrinol [Suppl 238] (Kbh) 94: 39-58

\section{Reiko Kawahara}

Jørn Ditzel

Section of Endocrinology

Department of Medicine

Aalborg Regional Hospital

DK-9000 Aalborg

Denmark

Table. Mean \pm SD of parameters measured in fasting nonacidotic ambulatory diabetic and healthy children (top). Linear regression equations, correlation coefficient (r) and statistical significance for the relationship between haemoglobin, haematocrit, erythrocyte count and haemoglobin $\mathrm{A}_{1}$ (bottom)

\begin{tabular}{|c|c|c|c|c|}
\hline & $\begin{array}{l}\text { Healthy children } \\
\mathrm{n}=30\end{array}$ & $\begin{array}{l}\text { Diabetic children } \\
n=43\end{array}$ & & Significance \\
\hline $\begin{array}{l}\text { Haemoglobin } \mathrm{g} / 100 \mathrm{ml} \\
\text { Haematocrit vol\% } \\
2,3-\mathrm{DPG} \mu \mathrm{mol} / 100 \mathrm{ml}\end{array}$ & $\begin{aligned} 13.0 & \pm 0.8 \\
0.37 & \pm 0.01 \\
189.1 & \pm 16.9\end{aligned}$ & $\begin{array}{c}13.7 \pm 1.0 \\
0.40 \pm 0.02 \\
207.6 \pm 17.7\end{array}$ & & $\begin{array}{l}p<0.005 \\
p<0.001 \\
p<0.001\end{array}$ \\
\hline Variables & & Linear regression & $\mathrm{r}$ & Significance \\
\hline $\begin{array}{l}\mathrm{Hb} \mathrm{g} \% / \mathrm{Hb} \mathrm{A} \\
\mathrm{Hct} \text { vol\%/Hb } \\
\text { Erythrocyte count } / \mathrm{Hb} \mathrm{A}_{\mathrm{I}}\end{array}$ & & $\begin{aligned} \mathrm{Hb} & =0.20 \quad \mathrm{Hb} \mathrm{A}_{\mathrm{I}}+11.13 \\
\mathrm{Hct} & =0.005 \mathrm{Hb} \mathrm{A}+0.33 \\
\text { Erythr } & =0.05 \quad \mathrm{Hb} \mathrm{A}_{\mathrm{I}}+4.02\end{aligned}$ & $\begin{array}{l}0.38 \\
0.38 \\
0.33\end{array}$ & $\begin{array}{l}p<0.05 \\
p<0.05 \\
p<0.05\end{array}$ \\
\hline
\end{tabular}

